\title{
Parametric Image
}

National Cancer Institute

\section{Source}

National Cancer Institute. Parametric Image. NCI Thesaurus. Code C94946.

An image where, instead of a customary parameter such as activity concentration, other computed results are displayed at each pixel (voxel) in their stead. 